\title{
Three-year assessment of one pre-licensure cohort of baccalaureate nursing students' attitude, comfort and knowledge of genomics
}

\author{
Leighsa Sharoff * \\ School of Nursing, Hunter College, New York, NY, United States
}

Received: July 7, 2017

DOI: $10.5430 /$ jnep.v7n12p114

\author{
Accepted: August 2, 2017 \\ Online Published: August 14, 2017 \\ URL: https://doi.org/10.5430/jnep.v7n12p114
}

\begin{abstract}
Objective: Descriptive three-year comparison of one pre-licensure cohort of baccalaureate nursing students' genomic knowledge, attitude and comfort level.

Methods: Two analyses were of interest, utilizing the same survey instrument, Genetics/Genomics Literacy Assessment (GGLA): 1) Comparison of pre vs. post intervention on the sophomore (2nd year) class and 2) Retention of the information through junior (3rd year) and senior year (4th year). Two analyses were of interest: 1) Comparison of pre-class vs. post-class assessment on sophomore [2nd year] students and 2) Retention of the information through junior [3rd year] and senior year [4th year].

Results: For the total score variable [retention of genomic knowledge over time] data was sophomore vs junior vs senior means of 7.1 vs. 6.9 vs. 8.7, $p<.001$ showing maintenance from sophomore (post-class assessment) to junior year with an increase in the senior year score for the cohort of students. Comparison of pre-class vs. post-class on the sophomore class resulted in statistically significant differences demonstrating higher knowledge after class. Enhancement of confidence, perceptions and attitude regarding genomics was evident with comparison of pre-class vs post-class and overtime after taking foundational course. Overall, data showed that students felt that nurse educators need more confidence in teaching and explaining as well as in patient advocacy.

Conclusions: Promoting knowledge and practice integration of universal genomic health requires healthcare professionals, educators and students be knowledgeable and cognizant of their participation to advance client health outcomes.
\end{abstract}

Key Words: Genomic knowledge, Comfort level, Attitude and perceptions, Pre-licensure

\section{INTRODUCTION}

For the current nursing workforce to be competent in genomic knowledge and comfortable in discussing and educating their patients and families about genetic conditions and genetic-directed therapies, pre-licensure students must be appropriately educated on this complex concept. Genomic competency is a requirement for all healthcare professionals and as such, nurses must be confident and comfortable in the translation of knowledge concerning integration of genomics into practice, research aspects and its implications and in policy-making concerning genetic evidence, knowledge and application. Though nurses who do not have a genomic counseling license/certificate are not allowed to discuss and educate patients/families about genetic condition and directed therapy, and pre-licensure nursing students would never engage in this process, it is still important to educate the student

*Correspondence: Leighsa Sharoff; Email: 1sharoff@ hunter.cuny.edu; Address: School of Nursing, Hunter College, New York, NY, United States. 
as to the importance of genomic knowledge, its implications in patient care, especially related to ethical and legal aspects, the importance of an accurate family history assessment, and their future role as a healthcare provider. Pre-licensure nursing curricula integration of genomic content should be able to provide core concepts leading to an informed future workforce utilizing precision evidence-based applied knowledge educating, explaining and effectively participating in the clinical care of patients and families with personalized attention. Continued exploration into actual, perceived and retained genomic knowledge amongst pre-licensure students, their comfort level in integrating this knowledge into their practice and future careers as healthcare professionals and their perception and attitude about genomic integration in nursing curricula is required. ${ }^{[1,2]}$ Current nursing students represent future nurse researchers, educators and healthcare professionals; subsequently, they must be skilled at assessing patients and their families for genetic risk and provide appropriate care and referrals.

\subsection{Purpose}

This 3-year convenience sample study explored one prelicensure cohort of baccalaureate nursing students, from a large diverse urban school of nursing (SON) in the United States, who completed a pre-class assessment survey prior to the beginning of the stand-alone required genetics course in their sophomore year (2nd year of nursing school), followed by a post-class assessment survey at the completion of that course (2014). The mechanism was identical for data collection, utilizing the Genetics/Genomics Literacy Assessment (GGLA), which was again administered at the beginning of their junior year (2015; 3rd year) and again as seniors (4th year) in 2016 to assess their retained genomic knowledge.

\subsection{Literature review}

With the emergence of the genomic era, all healthcare professionals are expected to be knowledgeable of genomic content, be able to integrate this knowledge into their practice and effectively participate in inter-disciplinary dialogue. Development of core essential genomic competencies for practicing nurses, advanced degree and pre-licensure students provided the benchmark for genomic education integration and a well-founded framework. ${ }^{[3-6]}$ To continue to provide maximum evidence-based personalized care, nurses need to maintain the minimum standard of knowledge in this required competency, assuring safety, professional accountability and responsibility. ${ }^{[7]}$

Numerous studies have explored pre-licensure selfreported/perceived genomic knowledge and comfort level. ${ }^{[2,8-13]}$ One of the initial analyzes of genomic knowl-

Published by Sciedu Press edge, the Genetics Literacy Assessment Instrument (GLAI), a 31-item multiple choice test, was utilized to assess undergraduate nonscience majors. ${ }^{[14]}$ It was viewed as a reliable assessment to track acquisition and retention of genomic concepts amongst nursing students and nurse educators and related coursework was found to enhance scores. ${ }^{[2]}$ A study utilizing the GLAI on nursing students revealed that although education perceptibly had an impact on total score, selfreported knowledge retention was lacking, with average total score of one cohort of students at $70 \%$ in $2013,67 \%$ in 2014 and $62 \%$ in 2015. ${ }^{[2]}$ Another instrument, a 15-item multiple choice survey, initially devised to explore baccalaureate nurse educators' self-perceived genetic knowledge in the United States, was validated to be an effective tool for clarity, accuracy and comprehensiveness. ${ }^{[12]}$ The adapted survey, Genetics/Genomics Literacy Assessment (GGLA), included concepts related to perceptions and attitudes about genetics incorporation into nursing programs and comfort level in practice and education, and was previously utilized to further explore nurse educators' and advanced degree nursing students. ${ }^{[12,15]}$ Nurses' fundamental self-confidence and comfort in genomic related accountabilities continues to be minimal. ${ }^{[16]}$ Having students rate their knowledge, attitude and comfort level of genomics demonstrated findings that expressed minimal to moderate knowledge as well as comfort levels, while expressing the need to know this knowledge as a practicing nurse. Inherently, data has continued to suggest that understanding educational concepts confirms the need for genomic education inclusion into curricula.

Actual knowledge of genomics of pre-licensure nursing students and practicing nurses is extremely limited, with one seminal study showing adequate genetic knowledge. ${ }^{[17]}$ With the development of the first nursing concept inventory, the Genomic Nursing Concept Inventory (GNCI), derived using a rigorous strategy common in science, technology, engineering and mathematics (STEM) education, measuring genomic literacy among nurses, actual knowledge of prelicensure and practicing nurses' foundational understanding of genomic concepts was assessed. ${ }^{[18]}$ This study's finding of pre-licensure baccalaureate nursing students in the United States also demonstrated that students' foundational knowledge was low while ABSN (accelerated Bachelor of Science in Nursing) program nursing students had a significantly higher GNCI score compared to traditional program students. ${ }^{[18]}$ This improvement perhaps reflects that prerequisite courses may offer "limited learning gains of concepts most relevant to nursing practice". ${ }^{[18]}$ However, a limitation to this actual knowledge study remains student willingness to partake in the study and respond to survey items to the best of their ability continues to be unknown. ${ }^{[18]}$ Besides 
actual versus self-reported knowledge, both surveys (GNCI and GGLA) were derived from competencies outlined in the AACN Essentials of Baccalaureate Education for Professional Nursing Practice, and the Essential of Genomic and Genomic Nursing: Competencies, Curricula Guidelines, and Outcomes Indicators. ${ }^{[4,5]}$ In either assessment, data demonstrates minimal acquisition of genomic knowledge.

Nursing faculty and practicing nurses continue to demonstrate limited foundational genomic knowledge, which unfortunately corresponds to students' knowledge preparation. The inadequacy to appropriately applying genomic advancements to meet the needs of the patient and family facing a genomic health compromise depicts the unpreparedness of the nursing profession. ${ }^{[19]}$ Understanding genomic concepts, knowledge deficit, lack of integration into nursing curricula and confidence in ability to teach this content exploits nursing faculty's inability to appropriately infuse into nursing education. Studies exploring nurse faculty and practicing nurses' foundational preparedness to implement genomic content has demonstrated minimal to moderate foundational knowledge and comfort levels. ${ }^{[15,20-26]}$ There is a genomic knowledge deficit correlating to a dearth in nurse educators' confidence to assimilate and disseminate genomic gen. ${ }^{[27]}$ Nursing faculty are required to prepare students for practice which includes the integration of genomic understanding and its application to practice, thus, knowledge and confidence in this content is a prerequisite. ${ }^{[19]}$

The continued relevance of genomic knowledge translation to clinical practice requires practicing nurses' incorporating and promoting personalized efficient and effective nursing care. A comparison data study of nurse educationalists and advanced degree nursing students' self-reported genomic knowledge and comfort level substantiated continued inconsistencies. ${ }^{[23]}$ Since the completion of the Human Genome Project in 2003 and human DNA genetic code sequencing in 2007, understanding the genomic impact on one's health and well-being is essential and vital for nurses to provide personalized genomic health care. ${ }^{[28]}$ Therefore, basic core scientific conceptual concepts to deliver genomic health care require nurses to have this knowledge ensuring they will be able to appropriately explain it to patient and their families. ${ }^{[19]}$ The fluctuation of a patient and their family's living experience with the complexity of a genetic condition will vary based on their life-stage/life-span and nurses need to provide information, education and referral guidance while participating in physical, emotional, spiritual and cultural support. ${ }^{[29]}$ Practicing nurse professionals are expected to have genomic health care knowledge to sufficiently and proficiently contribute as a concerted partner of the health care team.

\section{DESIGN, RECRUITMENT AND DATA COL- LECTION}

A descriptive comparison of one pre-licensure cohort of baccalaureate nursing students' genomic knowledge was explored. Prior to any data collection, which occurred between 2014-2016.

Consent by the original survey developer was received. ${ }^{[12]}$ The investigator modified the instrument to collect the specifications for this inquiry. Supplemental survey enquiries explored perception, attitude and comfort level to genomic inclusion into practice and demographic data. Institutional review board (IRB) consent was obtained for the utilization of the GGLA. An IRB-approved announcement script was read by proctors/research assistant (RA) prior to survey administration. Returning a completed survey deemed consent. Students were informed that they were not required to participate nor would their course grade be affected by not participating. There was no identifiable data obtained, voluntary participation was anonymous and confidentiality assured. No time limit was imposed to complete the survey. The researcher was not present during any of the data collection process.

Pre-class assessment data was obtained prior to the beginning of the sophomore level (2nd year) students' required genetic course in 2014, with the RA administering the IRB-approved survey at the conclusion of the first didactic class. At the completion of this didactic course, students were requested to complete the same survey, thus obtaining post-class assessment data. In both instances, the researcher, who was also the educator for this course, exited the classroom prior to the handing out of the survey. The researcher/educator initially developed the 2-credit class for the SON in 2013, after participating in the Genetics Program for Nursing Faculty at the Cincinnati Children's Hospital Medical Center. In 2015, the same cohort of students, as juniors (3rd year), were asked to retake the same survey and again in 2016, as seniors (4th year). The didactic educator, based on his/her teaching priorities, determined when it would be best to conduct the survey, as to not disrupt his/her class. Data collection for retained knowledge occurred either in the first two weeks or last two of the major didactic lecture, with the RA present to read the IRB-approved script and hand out/collect the survey.

Data was collected on multiple variables, including total score and correct responses to the survey (with no cut-off points), with score ranges from one to thirteen and correct ranges from 0 to 1.0 for the proportion correct. Perceptions and attitude about genomics integration into nursing curricula and comfort level about genomics were also explored. Perceptions and attitudes had seven variables and 
these ranged from $1=$ strongly agree to 4 = strongly disagree. Comfort level of genomics (five variables) ranged from $1=$ extremely comfortable through $4=$ not comfortable. Two analyses were of interest, utilizing the same survey instrument, GGLA: 1) Comparison of pre-class vs. post-class intervention in the sophomore year (2nd year), and 2) retention of knowledge through junior (3rd year) and senior years (4th year).

\subsection{Participants}

One pre-licensure cohort of baccalaureate nursing students were asked to participate in a 3-year study that explored their genomic knowledge, perception/attitude and comfort level. In 2014, as sophomores (2nd year students) in the SON, seventy-two students completed the pre-class survey prior to the beginning of their 2-credit stand-alone required genetics course and seventy students completed the post-class survey at the completion of that course. In 2015, the same students $(\mathrm{N}=68)$ were asked to complete the identical survey as juniors (3rd year) and again in 2016 as seniors $(\mathrm{N}=57$; 4th year) to assess their retained genomic knowledge. There was no exclusion criteria for participation, inclusion was being a student in the SON. All characteristics of the one cohort of students are in Table 1.

Table 1. Characteristics of one cohort of students

\begin{tabular}{|c|c|c|c|c|}
\hline Characteristics & $\begin{array}{l}\text { Sophomore } \\
\text { Pre-Class }(\mathrm{N}=72)\end{array}$ & $\begin{array}{l}\text { Sophomore } \\
\text { Post-Class }(N=69)\end{array}$ & $\begin{array}{l}\text { Junior } \\
(\mathrm{N}=\mathbf{6 8})\end{array}$ & $\begin{array}{l}\text { Senior } \\
(N=57)\end{array}$ \\
\hline \multicolumn{5}{|l|}{ Gender } \\
\hline Female $($ Total $\mathrm{N}=164)$ & $52(72.22)$ & $46(66.67)$ & $31(45.49)$ & $35(61.40)$ \\
\hline Male (Total $\mathrm{N}=102$ ) & $20(27.78)$ & $23(33.33)$ & $37(54.41)$ & $22(38.60)$ \\
\hline \multicolumn{5}{|l|}{ Age } \\
\hline $17-20($ Total $N=93)$ & $48(66.67)$ & $26(37.68)$ & $10(14.71)$ & $9(15.79)$ \\
\hline $21-24($ Total $\mathrm{N}=87)$ & $12(16.67)$ & $25(36.23)$ & $20(29.41)$ & $30(52.63)$ \\
\hline $25-28($ Total $N=58)$ & $10(13.89)$ & $12(17.39)$ & $22(32.35)$ & $14(24.56)$ \\
\hline 29-35 (Total N = 28) & $2(2.78)$ & $6(8.70)$ & $16(23.53)$ & $4(5.19)$ \\
\hline \multicolumn{5}{|l|}{ Ethnicity } \\
\hline American Indian (Total N = 7) & $3(4.17)$ & $2(2.90)$ & 0 & $2(3.51)$ \\
\hline Hispanic/Latino (Total N=37) & $16(22.22)$ & $5(7.25)$ & $11(16.18)$ & $5(8.77)$ \\
\hline Asian or Asian American (Total N = 130) & $37(51.36)$ & $38(55.07)$ & $26(38.15)$ & $19(50.88)$ \\
\hline Black or African American (Total $N=50$ ) & $5(6.94)$ & $9(13.04)$ & $23(33.82)$ & $13(22.31)$ \\
\hline White (Total $\mathrm{N}=42$ ) & $11(15.28)$ & $15(21.70)$ & $8(11.76)$ & $8(14.04)$ \\
\hline
\end{tabular}

Note. Total N = 266. Sophomore: (2014) Pre-Assessment [Pre-Class], Post-Assessment [Post-Class]; Junior (2015); Senior (2016)

\subsection{Instrument/assessment of genomic knowledge}

An enquiry ascertaining approaches to gage genomic knowledge lead to utilization of the corroborated survey. ${ }^{[12]}$ The initial 15 questions ranged from interpreting Mendelian inheritance diseases; genomic lexicon such as phenotypic polymorphism and allele; recognizing fertility inferences of a reciprocal translocation; construe genomic reciprocal translocation genetic testing; integrating uniform representations in a client's pedigree; associations concerning penetrance; understanding inheritance via pedigree and lawful protection from prejudice concerning one's genotype. The survey was appraised for breadth, lucidity and accurateness from three educationalists erudite in genomics and four affiliates of the International Society of Nurses in Genetics (ISONG) and was demonstrated to not be onerous or unreasonable to complete. ${ }^{[12]}$ Originally, the survey was conducted on baccalaureate nurse educators in the United States with additional studies performed deeming it suitable for exploring genomic knowledge with pre-licensure nursing students and advanced degree nursing students. ${ }^{[12-15]}$

Amendment to the initial survey (13 questions) comprised 7 additional enquiries exploring perceptions and attitudes about genomics inclusion and 5 enquiries exploring comfort level. Three demographic questions (age, gender and ethnicity) completed the modified survey, GGLA, totaling thirty questions. Perception and attitude had seven variables, which were: importance of genomic knowledge for a nurse; responsibility of preparing nurses; genomic education importance; family history assessment significance; motivation of clinical setting to learn about genomics and sharing knowledge; taking a genomic course helps to integrate content and advocating for patient and advocacy for patient and society concerning appropriate principled issues surrounding genomics. Comfort level about genomics was explored with five variables, related to gathering a patient's family history; requesting more education about genetic conditions for own knowledge base; explaining Mendelian inheritance patterns 
to patients and teaching the concepts of genomics and comfort in teaching genomic concepts. Clinical comfort with this complex learning parallels confidence if nursing professionals are to be co-participants with their patients and families in the healing-caring process. Validity and reliability of this tool was established to not be burdensome or time-consuming to complete, thus an effective instrument for assessment purposes. ${ }^{[12,15]}$

\subsection{Statistical analysis}

The three components of the survey (item score/correct response [with no cut-off points]; perceptions and attitudes about genomic merging into nursing curricula and comfort level about genomics) were analyzed using analysis of variance (ANOVA) tests. ANOVA was used because variables were approximately normally distributed. $P$-values less than or equal to alpha $=0.05$ were considered statistically signifi- cant, which is a common choice for alpha. Some subjects in the assessments remained the same over time, but data were not paired one-to-one as they were de-identified and thus the more conservative, independent assumption was used in the analyses.

\section{RESULTS}

\subsection{Comparison of pre-class vs post-class intervention on the sophomore year [2nd year]}

Comparison of survey item scores and correct responses for sophomore pre-class vs post-class assessment yielded similar results. Item score for pre-class was $7.3 \pm 2.05$ (mean $\pm \mathrm{SD}$; $\mathrm{N}=72)$ while the post-class was $7.1 \pm 2.44(\mathrm{~N}=69)$ with $p$-value .54. Correct responses also yielded similar findings with pre-class $0.5 \pm 0.14$ and post-class $0.5 \pm 0.16$ with a $p$-value also .54. Table 2 provides all GGLA item scores for the one cohort of students.

Table 2. GGLA item scores for one cohort of students

\begin{tabular}{|c|c|c|c|c|c|c|c|}
\hline Characteristic & & $\begin{array}{l}\text { Sophomore } \\
\text { Pre-Class (2014) }\end{array}$ & $\begin{array}{l}\text { Sophomore } \\
\text { Post-Class (2014) }\end{array}$ & $p$-value & $\begin{array}{l}\text { Junior } \\
\text { (2015) }\end{array}$ & $\begin{array}{l}\text { Senior } \\
\text { (2016) }\end{array}$ & $p$-value \\
\hline \multirow{4}{*}{ SCORE } & $\mathrm{N}$ & 72 & 69 & & 68 & 57 & \\
\hline & Mean \pm SD & $7.3 \pm 2.05$ & $7.1 \pm 2.44$ & .54 & $6.9 \pm 2.84$ & $8.7 \pm 2.69$ & $<.001$ \\
\hline & Range & 4.0 to 13.0 & 1.0 to 12.0 & & 1.0 to 12.0 & 3.0 to 13.0 & \\
\hline & Median & 7 & 7 & & 7 & 9 & \\
\hline \multirow{4}{*}{ CORRECT } & $\mathrm{N}$ & 72 & 69 & & 68 & 57 & \\
\hline & Mean \pm SD & $0.5 \pm 0.14$ & $0.5 \pm 0.16$ & .54 & $0.5 \pm 0.19$ & $0.6 \pm 0.18$ & $<.001$ \\
\hline & Range & 0.3 to 0.9 & 0.1 to 0.8 & & 0.1 to 0.8 & 0.2 to 0.9 & \\
\hline & Median & 0.5 & 0.5 & & 0.5 & 0.6 & \\
\hline
\end{tabular}

Comparison of pre-class vs post-class in their perception and attitude about genomics integration into nursing curricula resulted in statistical differences for several variables, especially history taking, whereby the scores went down significantly from pre-class to post-class indicating higher agreement post-class intervention compared to pre-class. On the history taking variable, an average of 3.4 pre-class went down to an average score of 2.5 post-class intervention (mean $\pm \mathrm{SD}$ : pre-class $3.4 \pm 0.93$ vs. post-class $2.5 \pm 1.21$, $p$ value $<.001)$. This result represents a more strong agreement of enhanced perceptions and attitude after completion of foundational class (post-class assessment). Educating nurses about genomics to ensure their continued partnership in patient/family care variable, there was no statistically significant change from pre-class to post-class (Mean $\pm \mathrm{SD}$ : pre-class $1.4 \pm 0.62$ vs. post-class $1.4 \pm 0.74, p$-value $=$ 97). Table 3 provides the perceptions and attitudes about genomics inclusion into nursing curricula for the one cohort of students.

For the five comfort level variables (collecting, sharing, requesting, explaining and teaching), the scores also went down significantly from pre-class to post-class indicating higher comfort post intervention. On the collecting variable, an average of 2.8 pre-class went down to an average score of 2.0 post-class intervention (mean $\pm \mathrm{SD}$ : pre-class $2.8 \pm 1.07$ vs. post-class $2.0 \pm 0.82, p$-value $<.001)$. For the sharing variable, the average of 2.7 pre-class went down to an average score of 2.0 post-class intervention (mean \pm SD: pre-class $2.7 \pm 1.04$ vs post-class $2.0 \pm 0.88, p$-value $<.001$ ). On the explaining variable, an average of 2.7 pre-class went down to an average score of 2.0 post-class intervention (mean \pm SD: pre-class $2.7 \pm 1.20$ vs. post-class $2.0 \pm 0.88, p$-value $<.001)$. Finally, for the comfort level related to teaching, the scores went down significantly from pre-class to postclass indicating higher agreement post-class intervention. As seen in Table 4 the comfort level about genomics for the 
one cohort of students, perception and attitude as well as foundational course.

confidence levels were enhanced after taking the stand-alone

Table 3. Perceptions and attitudes about genomics integration into nursing curricula for one cohort of students

\begin{tabular}{|c|c|c|c|c|c|c|c|c|}
\hline Characteristic & & $\begin{array}{l}\text { Pre-Class } \\
\mathrm{N}=72\end{array}$ & $\begin{array}{l}\text { Post-Class } \\
\mathrm{N}=69\end{array}$ & $p$-value & $\begin{array}{l}\text { Sophomore } \\
N=69\end{array}$ & $\begin{array}{l}\text { Junior } \\
N=68\end{array}$ & $\begin{array}{l}\text { Senior } \\
N=57\end{array}$ & $p$-value \\
\hline $\begin{array}{l}\text { IMPORTANCE } \\
\text { for nurses to know }\end{array}$ & $\begin{array}{l}\text { Mean } \pm \text { SD } \\
\text { Median }\end{array}$ & $\begin{array}{l}1.4 \pm 0.64 \\
1\end{array}$ & $\begin{array}{l}1.4 \pm 0.60 \\
1\end{array}$ & .95 & $\begin{array}{l}1.4 \pm 0.60 \\
1\end{array}$ & $\begin{array}{l}1.9 \pm 1.07 \\
2\end{array}$ & $\begin{array}{l}1.4 \pm 0.60 \\
1\end{array}$ & $<.001$ \\
\hline $\begin{array}{l}\text { PREPARING } \\
\text { nurses is role of nurse } \\
\text { educators }\end{array}$ & $\begin{array}{l}\text { Mean } \pm \text { SD } \\
\text { Median }\end{array}$ & $\begin{array}{l}1.4 \pm 0.57 \\
1\end{array}$ & $\begin{array}{l}1.5 \pm 0.87 \\
1\end{array}$ & .40 & $\begin{array}{l}1.5 \pm 0.87 \\
1\end{array}$ & $\begin{array}{l}1.6 \pm 0.78 \\
1\end{array}$ & $\begin{array}{l}1.5 \pm 0.76 \\
1\end{array}$ & .78 \\
\hline $\begin{array}{l}\text { TEACHING } \\
\text { nurses genomics is important }\end{array}$ & $\begin{array}{l}\text { Mean } \pm \text { SD } \\
\text { Median }\end{array}$ & $\begin{array}{l}1.4 \pm 0.62 \\
1\end{array}$ & $\begin{array}{l}1.4 \pm 0.74 \\
1\end{array}$ & .97 & $\begin{array}{l}1.4 \pm 0.74 \\
1\end{array}$ & $\begin{array}{l}2.0 \pm 1.18 \\
1.5\end{array}$ & $\begin{array}{l}1.4 \pm 0.57 \\
1\end{array}$ & .002 \\
\hline $\begin{array}{l}\text { HISTORY TAKING } \\
\text { value for patient care }\end{array}$ & $\begin{array}{l}\text { Mean } \pm \text { SD } \\
\text { Median }\end{array}$ & $\begin{array}{l}3.4 \pm 0.93 \\
4\end{array}$ & $\begin{array}{l}2.5 \pm 1.21 \\
2.5\end{array}$ & $<.001$ & $\begin{array}{l}2.5 \pm 1.2 \\
2.5\end{array}$ & $\begin{array}{l}2.2 \pm 1.26 \\
2\end{array}$ & $\begin{array}{l}2.8 \pm 1.26 \\
3\end{array}$ & .05 \\
\hline $\begin{array}{l}\text { ENVIRONMENT } \\
\text { motivating to learn about } \\
\text { genomics }\end{array}$ & $\begin{array}{l}\text { Mean } \pm \text { SD } \\
\text { Median }\end{array}$ & $\begin{array}{l}1.9 \pm 0.82 \\
2\end{array}$ & $\begin{array}{l}1.8 \pm 0.88 \\
2\end{array}$ & .79 & $\begin{array}{l}1.8 \pm 0.88 \\
2\end{array}$ & $\begin{array}{l}2.2 \pm 0.98 \\
2\end{array}$ & $\begin{array}{l}2.2 \pm 0.98 \\
2\end{array}$ & .06 \\
\hline $\begin{array}{l}\text { INTEGRATE } \\
\text { genomic course helpful for } \\
\text { practice }\end{array}$ & $\begin{array}{l}\text { Mean } \pm \text { SD } \\
\text { Median }\end{array}$ & $\begin{array}{l}1.6 \pm 0.65 \\
2\end{array}$ & $1.5 \pm 0.1$ & .38 & $\begin{array}{l}1.5 \pm 0.68 \\
1\end{array}$ & $\begin{array}{l}2.0 \pm 0.83 \\
2\end{array}$ & $\begin{array}{l}1.7 \pm 0.86 \\
2\end{array}$ & .001 \\
\hline $\begin{array}{l}\text { ADVOCATE } \\
\text { for patient and importance of } \\
\text { nurses to advocate for patient } \\
\text { and society regarding ethical } \\
\text { and legal issues about } \\
\text { genomics }\end{array}$ & $\begin{array}{l}\text { Mean } \pm \text { SD } \\
\text { Median }\end{array}$ & $\begin{array}{l}1.6 \pm 0.75 \\
1\end{array}$ & $\begin{array}{l}1.5 \pm 0.72 \\
1\end{array}$ & .43 & $\begin{array}{l}1.5 \pm 0.72 \\
1\end{array}$ & $\begin{array}{l}1.6 \pm 0.97 \\
1\end{array}$ & $\begin{array}{l}1.4 \pm 0.62 \\
1\end{array}$ & .17 \\
\hline
\end{tabular}

Table 4. Comfort level about genomics for one cohort of students

\begin{tabular}{|c|c|c|c|c|c|c|c|c|}
\hline Characteristic & & $\begin{array}{l}\text { Pre-Class } \\
\mathrm{N}=72\end{array}$ & $\begin{array}{l}\text { Post-Class } \\
\mathrm{N}=69\end{array}$ & $p$-value & $\begin{array}{l}\text { Sophomore } \\
N=69\end{array}$ & $\begin{array}{l}\text { Junior } \\
N=68\end{array}$ & $\begin{array}{l}\text { Senior } \\
N=57\end{array}$ & $p$-value \\
\hline $\begin{array}{l}\text { COLLECTING } \\
\text { a patient's family history }\end{array}$ & $\begin{array}{l}\text { Mean } \pm \text { SD } \\
\text { Median }\end{array}$ & $\begin{array}{l}2.8 \pm 1.07 \\
3\end{array}$ & $\begin{array}{l}2.0 \pm 0.82 \\
2\end{array}$ & $<.001$ & $\begin{array}{l}2.0 \pm 0.82 \\
2\end{array}$ & $\begin{array}{l}1.9 \pm 0.90 \\
2\end{array}$ & $\begin{array}{l}2.3 \pm 0.92 \\
2\end{array}$ & .05 \\
\hline $\begin{array}{l}\text { SHARING } \\
\text { sharing knowledge of genomics }\end{array}$ & $\begin{array}{l}\text { Mean } \pm \text { SD } \\
\text { Median }\end{array}$ & $\begin{array}{l}2.7 \pm 1.04 \\
3\end{array}$ & $\begin{array}{l}2.0 \pm 0.88 \\
2\end{array}$ & $<.001$ & $\begin{array}{l}2.0 \pm 0.88 \\
2\end{array}$ & $\begin{array}{l}2.1 \pm 0.98 \\
2\end{array}$ & $\begin{array}{l}2.6 \pm 0.85 \\
3\end{array}$ & $<.001$ \\
\hline $\begin{array}{l}\text { REQUESTING } \\
\text { requesting more education } \\
\text { about genetic conditions for } \\
\text { own knowledge base }\end{array}$ & $\begin{array}{l}\text { Mean } \pm \text { SD } \\
\text { Median }\end{array}$ & $\begin{array}{l}2.3 \pm 0.9 \\
2\end{array}$ & $\begin{array}{l}2.1 \pm 0.84 \\
2\end{array}$ & .12 & $\begin{array}{l}2.1 \pm 0.84 \\
2\end{array}$ & $\begin{array}{l}2.2 \pm 1.04 \\
2\end{array}$ & $\begin{array}{l}2.2 \pm 1.02 \\
2\end{array}$ & .50 \\
\hline $\begin{array}{l}\text { EXPLAINING } \\
\text { explaining concepts of } \\
\text { genomics }\end{array}$ & $\begin{array}{l}\text { Mean } \pm \text { SD } \\
\text { Median }\end{array}$ & $\begin{array}{l}2.7 \pm 1.20 \\
3\end{array}$ & $\begin{array}{l}2.0 \pm 0.88 \\
2\end{array}$ & $<.001$ & $\begin{array}{l}2.0 \pm 0.88 \\
2\end{array}$ & $\begin{array}{l}2.4 \pm 0.91 \\
2\end{array}$ & $\begin{array}{l}2.3 \pm 1.10 \\
2\end{array}$ & .03 \\
\hline $\begin{array}{l}\text { TEACHING } \\
\text { genomic concepts }\end{array}$ & $\begin{array}{l}\text { Mean } \pm \text { SD } \\
\text { Median }\end{array}$ & $\begin{array}{l}2.6 \pm 1.22 \\
3\end{array}$ & $\begin{array}{l}2.2 \pm 0.92 \\
2\end{array}$ & $\begin{array}{l}.02 \\
2\end{array}$ & $\begin{array}{l}2.2 \pm 0.92 \\
2\end{array}$ & $\begin{array}{l}2.5 \pm 0.88 \\
3\end{array}$ & $\begin{array}{l}2.6 \pm 0.87 \\
3\end{array}$ & .02 \\
\hline
\end{tabular}

\subsection{Retention of information overtime (Junior [3rd] and Senior [4th] years)}

Comparison of survey item score, data showed sophomore post-class $(\mathrm{N}=69)$ vs. junior $(\mathrm{N}=68)$ vs. senior $(\mathrm{N}=57)$ mean $\pm \mathrm{SD}$ was $7.1 \pm 2.44$ vs. $6.9 \pm 2.84$ vs. $8.7 \pm 2.69$ with $p<.001$. Correct response score was post-class 0.5 \pm 0.16 vs. junior $0.5 \pm 0.19$ and senior $0.6 \pm 0.18$ with $p$-value $<.001$. Both sets of data demonstrate maintenance from sophomore to junior year with an increase in item score and correct responses in the senior year (see Table 2).

Published by Sciedu Press
With regards to perceptions and attitude about genomics integration into nursing curricula, significant changes in information were found over time. For importance, integrating, and teaching variables, data results showed that in the junior year $(\mathrm{N}=68)$ there was an increase which then went back down in senior year to the values found sophomore year. History taking and collecting variables showed results went down during the junior year but then increased as seniors (see Table 3).

For the comfort level variables (collecting, sharing, request- 
ing, explaining and teaching), collecting variables showed results went down during the junior year but then increased as seniors while explaining increased in the junior year and then decreased in the senior year to comfort level related to sophomore year. Teaching comfort level increased each year, demonstrating seniors having the most comfort with teaching genomic content (mean \pm SD was $2.2 \pm 0.92$ vs. $2.5 \pm 0.88$ vs. $2.6 \pm 0.87$ with $p$-value $=.02$ ). Overall, the sharing variable demonstrated maintenance from sophomore to junior year with an increase in the senior year (mean $\pm \mathrm{SD}$ was $2.0 \pm 0.88$ vs. $2.1 \pm 0.98$ vs. $2.6 \pm 0.85$ with $p$-value < .001 ; see Table 4 ).

\section{Discussion}

Comparison of survey item scores and correct responses for sophomore pre-class vs post-class assessment yielded similar results, maintenance from sophomore to junior year and an increase in the senior year. This may have been dependent on the post-class assessment being only 14 weeks after the pre-class survey, thus, many of the students remembered answering these questions and rather than spend time reading and evaluating what they felt the correct answer was, perhaps they chose based on what they remembered from the initial pre-class survey. Findings from a large program study with the GNCI demonstrated scores peaking immediately after completion of a required genomics course with scores decreasing by graduation. ${ }^{[30]}$ Although education has a definite impact on knowledge, retaining that knowledge over time is not always evident. ${ }^{[2]}$ Furthermore, it is impossible to convince students to spend a certain amount of time answering survey questions. ${ }^{[31]}$ This correlates to the continued uncertainty of student engagement and unknown factors related to their efforts when completing a survey assessment. ${ }^{[18]}$ The importance of a genomic health history was perceived as having value for patient care. Current baccalaureate nursing students' agree that the significance of a comprehensive family health history and its genomic implications are integral to the nurses' ability to provide optimal patient care and patient education. ${ }^{[32]}$ Practicing nurses continue to have limited knowledge of genetic terms, disorders and facts within a family history. ${ }^{[26]}$ The higher the educational preparation, the greater the nurse's confidence in deciding which family history information is necessary to assess a person's genetic predisposition to common diseases. ${ }^{[7]}$ Given that the junior class assessment was at the beginning of their fall semester, knowledge retention was maintained, with scores increasing in their senior year. Students' self-perceived knowledge improved from sophomore year to senior year, suggesting that continued integration of content may have been threaded through the SON curriculum, most likely in the core didactic courses, such as medical/surgical nursing, maternal/child nursing, pediatrics, and psychiatric/mental health. As genetics was a stand-alone course offered in the students' sophomore year, content necessities frequent threading within nursing curricula to substantively expand students' genomic knowledge.

Senior nursing students have already begun to think about and study for the National Council Licensure Examination (NCLEX-RN), a nationwide examination for the licensing of nurses in the United States and Canada. ${ }^{[31,33]}$ By practicing NCLEX questions students recall information that was learned and learn how to apply the knowledge. ${ }^{[34]}$ The certification process in the United Kingdom, the Nursing and Midwifery Council (NMC), regulates nurses and midwives in England, Wales, Scotland and Northern Ireland, setting standards of education, training, conduct, performance and registering nurses and midwives when they have successfully completed their courses. ${ }^{[35]}$ The Australian Health Practitioner Regulation Agency (AHPRA) in conjunction with The Nursing and Midwifery Board of Australia oversees the registration process. ${ }^{[36]}$ In Japan, pre-licensure nursing students must pass the national licensing examination and obtain a license administered by the Division of Nursing of the Ministry of Health, Labour, and Welfare. ${ }^{[37]}$ However, specific genomic content on these regulatory examinations are not known.

In addition, HESI exams are administered to students, in many U.S. nursing programs, to prepare them for the NCLEX Exam. ${ }^{[38]}$ HESI test questions are developed and formatted to the likeness of the NCLEX exam. School of Nursing BSN students may take up to five exams consisting of four specialties and one Exit Exam. The specialty exams are administered in the Medical/Surgical, Maternity, Pediatrics, and Psychiatric subject areas. The Exit Exam consists of all four subject areas. ${ }^{[38]}$ There are genetics questions dispersed throughout the categories, but there is no genetics category. ${ }^{[34]}$ This makes it difficult for students to practice recalling and applying the genetics knowledge they have learned. Maybe HESI should add a genetics category, so students can better practice questions related to the genetics knowledge they learned and prepare them to use their genetics knowledge in the healthcare setting. ${ }^{[34]}$ Faculty need to keep abreast of the required genomics competencies, with respect to national licensing regulatory detailed-examination assessment, whilst continually integrating these concepts to identify gaps in genomic content and revise their curriculum accordingly. ${ }^{[1]}$

Perception, attitude and comfort level about genomics, by all three cohort groups, continues to demonstrate the importance of genomic health awareness. Genomic health care is 
now an integral part of everyday practice with the consumer being cognizant of its importance. ${ }^{[39]}$ As nursing students begin their journey towards professional practice, enhancing their perceptions, attitude and confidence in their ability and understanding of genomic health is essential. Most nurses still demonstrate limited perceived knowledge and clinical comfort. ${ }^{[11]}$ As the nursing workforce is exposed to genomic content, both in the academic and clinical setting, confidence in this highly complex domain will expand. Concentrating on academic education is a priority given that it positively impacts knowledge, attitude and confidence. ${ }^{[7]}$ Concurrently, senior nursing students' exposure to clinical experiences further impacts their ability to comprehend and assimilate knowledge. As a significant number of pre-licensure students have practicing nurses' as clinical preceptors, ensuring all levels of the nursing workforce understand genomic health care is essential. The gap in genomic knowledge, of educators in both academia and the clinical setting, must be addressed. As comfort improves, confidence improves and patient outcomes are enhanced. The first step towards this is the confidence and capability to fully implement and integrate the standards of genomic competency into the academic setting.

\section{Limitations}

The convenience sample may not sufficiently characterize pre-licensure students in other programs. Given that data was de-identified, there was no mechanism to determine which participants' retained knowledge improved or diminished over the course of their educational process. Surveying for the retention of knowledge in either the first two weeks or the last two weeks of the students' core didactic course provided additional inconsistency to the methodology. Initial changes may not have been represented as students did not have any additional nursing background in the application with their knowledge. Retention was more difficult to assess because it was not always the same exact set of students across the years. A significant limitation was the scantrons that participants used for the survey had to be hand-graded by the RA as the SON scantron machine was non-functioning. Genomic subject mapping interspersed through the curriculum has not been conducted at this SON. Therefore, future studies would be reinforced by connecting concepts threaded through the curriculum. Though this study is based on selfreported findings, relevance to students' knowledge base remains inconsistent related to perceived versus actual genetics knowledge. ${ }^{[1]}$ Future research would be to follow this study with focus groups of semi-structured interviews to also obtain rich data on the student nurses opinions. The study's findings and discussion should be considered within these restraints.

\section{Conclusion}

The genomic era impacts nursing education and practice in a multitude of ways. The nursing profession must meet the challenge to prepare future practitioners by incorporating genomic content continuously through-out the curricula and clinical experiences. With the advancements occurring in genomic heath care, genetics is becoming more important in understanding individuals' risks and best treatment options for different conditions. All healthcare professionals need to become more proficient in their knowledge of genetics. ${ }^{[34]}$ Nursing as a whole must assume a proactive role in reinforcing this complex content to meet the multifaceted demands of personalized precision patient care.

\section{ACKNOWLEDGements}

The author would like to thank all the students those who participated in this study and research assistants. A special thank you to Ms. Talia Rosenbloom, the author's mentee for the Hunter College 2017 Undergraduate Research Fellowship, who assisted in data collection and analysis. The author received no extramural funding and no commercial financial support in this research.

\section{CONFlicts of InTEREST Disclosure}

The author declares that there is no conflict of interest.

\section{REFERENCES}

[1] Munroe T, Loerzel V. Assessing nursing students' knowledge of genomic concepts and readiness for use in practice. Nurse Educator. 2016; 41(2): 86-89. http://doi.org/10.1097/NNE. 00000000 00000210

[2] Sharoff L. Perceived Genetic Knowledge in Pre-Licensure Nursing Students. Journal of Nursing Education and Practice. 2017; 7(2): 10-17. http://doi.org/10.5430/jnep.v7n2p10

[3] National Coalition for Health Professional Education in Genetics (NCHPEG). Core Competencies in Genetics Essential for All Health-Care Professionals. 2007; 3rd Ed. Available from: https://www.jax.org/education-and-learning/cl inical-and-continuing-education

[4] American Association of Colleges of Nursing. The Essentials of Baccalaureate Education for Professional Nursing Practice. Washington, DC: American Association of Colleges of Nursing. 2008. Available from: http://www.aacn.nche.edu/education-resources/B accEssentials08.pdf

[5] Consensus Panel on Genetic/Genomic Nursing Competencies. Essentials of Genetic and Genomic Nursing: Competences, 
Curricula Guidelines, and Outcome Indicators. 2009. Available from: https://www.genome.gov/pages/careers/healthpro fessionaleducation/geneticscompetency.pdf

[6] Thompson H, Brooks M. Genetics and genomics in nursing: Evaluating essentials implementation. Nurse Educator Today. 2011; 31(6): 623-627. https://doi .org/10.1016/j.nedt. 2010.10.023

[7] Calzone K, Jenkins J, Culp S, et al. Introducing a new competency into nursing practice. Journal of Nursing Regulation. 2014; 5(1): 40-47. https://doi .org/10.1016/S2155-8256(15) 30098-3

[8] Maradiegue A, Edwards QT, Seibert D, et al. Knowledge, perceptions and attitudes of advanced practice nursing students regarding medical genetics. Journal of the American Academy of Nurse Practitioners. 2005; 17: 472-479. https://doi.org/10.1111/j.1745-7599. $2005.00076 . x$

[9] Kiray B, Tomatir A, Kuzu Kurban K, et al. Nursing Students' SelfReported Knowledge of Genetics and Genetic Education. Public Health Genomics. 2009; 12(4): 225-232. https ://doi .org/10.1 $159 / 000197972$

[10] Dodson C, Lewallen L. Nursing students' perceived knowledge and attitude towards genetics. Nurse Education Today. 2011; 31(4): 333339. https://doi.org/10.1016/j.nedt. 2010.07.001

[11] Hsiao C, Riper M, Lee S, et al. Taiwanese Nursing students' perceived knowledge and clinical comfort with genetics. Journal of Nursing Scholarship. 2011; 43(2): 125-132. https ://doi .org/10 $.1111 / j .1547-5069.2011 .01389 . x$

[12] DeSevo M. Competency of nurse educators in genetics/genomics knowledge. Journal of Nursing Education and Practice. 2013; 3(1): 123-129. https://doi.org/10.5430/jnep.v3n1p123

[13] St-Martin G, Bedard A, Nelmes J, et al. Preparing Nurses for Genetic Medicine: Integration of a Brief Education Session in an Undergraduate Nursing Curriculum. Journal of Nursing Education. 2017; (56)3: 170-173. https://doi.org/10.3928/01484834-20170 222-09

[14] Bowling B, Acra E, Wang L, et al. Development and evaluation of a Genetics Literacy Assessment Instrument for undergraduates. Genetics. 2008; 178: 15-22. https://doi.org/10.1534/genetics.1 07.079533

[15] Sharoff L. Comparison of Perceived Genetic Knowledge of Nurse Educators and Graduate Degree Nursing Students. Journal of Nursing Education and Practice. 2017; 7(9): 67-71. https ://doi .org/10 .5430/jnep.v7n9p67

[16] Skirton H, O'Connor A. Humphreys A. Nurses' competence in genetics: A mixed method systematic review. Journal of Advanced Nursing. 2012; 68(11): 2387-2398.

[17] Cohen F. Genetics knowledge possessed by American nurses and nursing students. Journal of Advancement in Nursing. 1979; 4(5): 493-501. https://doi.org/10.1111/j.1365-2648.19 79.tb00883.x

[18] Ward L, Purath J, Barbosa-Leiker C. Assessment of genomic literacy among baccalaureate nursing students in the United States: A Feasibility Study. Nurse Educator. 2016; 41(6): 313-318. https: //doi.org/10.1097/NNE.0000000000000272

[19] Camak D. Increasing important of genetics in nursing. Nurse Education Today. 2016; 22: 86-91. https://doi.org/10.1016/j.ne dt.2016.05.018

[20] Greco K, Tinley S, Seibert D. Development of the essential genetic and genomic competencies for nurses with graduate degrees.
Annual Review of Nursing Research. 2011; 29: 173-190. https: //doi.org/10.1891/0739-6686.29.173

[21] Jenkins J, Calzone K. Are nursing faculty ready to integrate genomic content into curricula. Nurse Educator. 2012; 37(1): 25-29. https://doi.org/10.1097/NNE.0b013e31823836ec

[22] Calzone K, Jenkins J, Culp S, et al. National nursing workforce survey of nursing attitudes, knowledge and practice in genomics. Personalized Medicine. 2013; 10(7): 719-728. PMid:24363765 https://doi.org/10.2217/pme.13.64

[23] Maradiegue A, Edwards QT, Seibert D. 5-years later - have faculty integrated medical genetics into nurse practitioner curriculum? International Journal of Nursing Education Scholarship. 2013; 10: 245-254. https://doi.org/10.1515/ijnes-2013-0094

[24] Sharoff L. Enhancing Sickle Cell Anemia/Sickle Cell Disease Genetic Understanding through Simulation: A Descriptive Pilot Study. Journal of Nursing Education and Practice. 2015; 5(9): 39-48. https://doi.org/10.5430/jnep.v5n9p39

[25] Read C, Ward L. Faculty Performance on the Genomic Nursing Concept Inventory. Journal of Nursing Scholarship. 2016; 48(1): 5-13. https://doi.org/10.1111/jnu.12175

[26] Rogers M, Lizer S, Doughty A, et al. Expanding RN scope of knowledge - Genetics/Genomics: The New Frontier. Journal for Nurses in Professional Development. 2017; 33(2): 56-61. https : //doi.org/10.1097/NND.0000000000000340

[27] Read C, Ricciardi C, Gruhl A, et al. Building genetic competence through partnerships and interactive models. Journal of Nursing Education. 2016; 55(5): 300-303.

[28] National Institute of Health. National Human Genome Research Institute (NHGRI). 2003. Available from: http: //www.genome.gov $/ 10001772$

[29] Sharoff L. Holistic nursing in the Genetic/Genomic Era. Journal of Holistic Nursing. 2016; 34(2): 146-153. https ://doi .org/10.1 $177 / 0898010115587401$

[30] Ward L. A model for evaluating genomic nursing education. Paper presented at the International Society of Nurses in Genetics World Congress, October 2016; Bethesda, MD.

[31] Rosenbloom, Talia. Personal electronic mail message communication. Message to: Leighsa Sharoff. April 27, 2017. [1 paragraph].

[32] De Jesus M, Mitchel M. Today's nurses need genetics education. Nursing2017. 2016; 46(10): 68

[33] National Council of State Boards in Nursing (NCSBN). (2017). Available from: https://www.ncsbn.org/nclex.htm

[34] Rosenbloom, Talia. Personal electronic mail message communication. Message to: Leighsa Sharoff. May 3, 2017. [2 paragraphs].

[35] Nursing and Midwifery Council (NMC). 2017. Available from: https://www.nmc.org.uk/about-us/our-role/

[36] Australian Health Practitioner Regulation Agency (AHPRA). 2017. Available from: https://www . ahpra.gov.au/

[37] Ministry of Health, Labour, and Welfare (MHLW). 2017. Available from: http://www.mhlw.go.jp/english/https://doi.org/ 10.3928/01484834-20160414-12

[38] Evolve-Elsevier. 2017. HESI exams. Available from: https://ev olve.elsevier.com/education/hesi/

[39] Andrews V, Tonkin E, Lancastle D, et al. Using the diffusion of innovations theory to understand the uptake of genetics in nursing practice: Identifying the characteristics of genetic nurse adopters. Journal of Advanced Nursing. 2014; 70(4): 878-893. https : //doi. org/10.1111/jan. 12255 